\title{
ABL1 Gene Rearrangement
}

National Cancer Institute

\section{Source}

National Cancer Institute. ABL1 Gene Rearrangement. NCI Thesaurus. Code C131490.

A molecular abnormality indicating rearrang ement of the ABL1 gene. 